DOI:

Микола Галів, доктор педагогічних наук, доцент кафедри історії Украӥни Дрогобицького державного педагогічного університету імені Івана Франка

\title{
ІДЕОЛОГІЧНА КРИТИКА В УКРАЇНСЬКОМУ РАДЯНСЬКОМУ ІСТОРИКО-ПЕДАГОГІЧНОМУ НАРАТИВІ (1920-1980)
}

У статті виокремлено і проаналізовано прояви критики різних ідеологій в украӥнському історикопедагогічному наративі радянської доби (1920-1980-ті рр.). Встановлено, щзо під тиском притаманної радянському тоталітаризму моноідеологічності, а саме иілковитого домінування однієї ідеологї̈ (сочіалістичної у формі “марксизму-ленінізму”), у вітчизняному історико-педагогічному наративі звичними стали очінки фактів і процесів педагогічної минувиини крізь призму саме ідеологічних постулатів. Це проявилося, зокрема, у критиці ліберальних, соціал-демократичних, націоналістичних, націоналсоціалістичних, консервативних ідей та їхніх репрезентантів в освіті і педагогічній науці.

Ключові слова: історія педагогіки; наратив; ідеологія; лібералізм; сочіал-демократія; начіоналізм; тоталітаризм.

Jim. 30.

Mykola Haliv, Doctor of Sciences (Pedagogy), Associate Professor of the History of Ukraine Department, Drohobych Ivan Franko State Pedagogical University

\section{CRITICISM OF IDEOLOGIES IN THE UKRAINIAN SOVIET HISTORICALAND PEDAGOGICAL NARRATIVE (1920s - 1980s)}

The purpose of the article is to single out and analyze the manifestations of criticism of different ideologies in the Ukrainian historical and pedagogical narrative of the Soviet era (1920-1980's). The study of the methodological foundation of Ukrainian historical and pedagogical science is not possible without considering the influence of ideological doctrines on the scientific work of domestic scientists who have studied the history of pedagogical thought and education. In the XXth century the largest influence on the historical and pedagogical texts of Ukrainian researchers was exerted by the socialist ideology of the Marxist model, being, in fact, the only state doctrine in the Soviet Union in general and Soviet Ukraine in particular. The ideological dictatorship of pedagogical and historicalpedagogical science, being under totalitarianism, among the defense of the basic theoretical constructs of socialist ideology (so-called "Marxism-Leninism"), provided an uncompromising struggle against other ideological systems. Ukrainian researchers who lived and worked in Soviet Ukraine criticized liberal, social democratic, nationalist, fascist, and National Socialist ideas and their representatives, even the researching of history of education and pedagogy.

In addition, the influence of the complex intra-party struggle in the USSR on the work of historians of pedagogy has been studied. In particular, it is investigated that the critique of the ideas of L. Trotsky, M. Bukharin, the views of M. Skrypnyk, O. Shumskiy appeared in the works of researchers of the history of education and pedagogical thought.

We consider the identification and analysis of other aspects of the influence of socialist ideology and propaganda to be a promising area of further research.

Keywords: history of pedagogy; narrative; ideology; liberalism; social democracy; nationalism; totalitarianism.

П

остановка проблеми. Дослідження методологічного фундаменту української історико-педагогічної науки неможливебез розгляду впливу ідеологічних доктрин на наукову творчість вітчизняних учених, які досліджували історію педагогічної думки та освіти. У ХХ ст. найбільш масштабний вплив на історикопедагогічні тексти українських дослідників справила соціалістична ідеологія марксистського зразка, будучи, посуті, єдиною державною доктриною в Радянському Союзі загалом та радянській Україні зокрема. В умовах тоталітаризму ідеологічний диктат у педагогічній та історико-педагогічній науці, серед відстоювання засадничих теоретичних конструктів соціалістичної (так званої “марксистсько-ленінської”) ідеології, передбачав i безкомпромісну боротьбу проти інших ідеологічний систем: лібералізму, консерватизму, націоналізму та їхніх різновидів, а також “нерадянського" соціалізму. Прояви такої “ідеологічної війни” в українському історикопедагогічному наративі радянської доби (19201980) потребує окремого аналізу.

Аналіз останніх досліджень. Вплив соціалістичної ідеології на вітчизняний історико- 


\section{ІДЕОЛОГІЧНА КРИТИКА В УКРАЇНСЬКОМУ РАДЯНСЬКОМУ ІСТОРИКО-ПЕДАГОГІЧНОМУ НАРАТИВІ (1920-1980)}

педагогічний наратив досліджували Л. Ваховський, Н. Гупан, О. Сухомлинська, О. Стражнікова. Найбільш повно зазначена проблема охарактеризована у монографії М. Галіва (2018), в якій окреслювалася критика істориками педагогіки радянської доби усіх політичних ідеологій, які хоча 6 у чомусь суперечили соціалістичному вченню "марксистськоленінського” взірця та становили конкуренцію для нього [2]. Уважаємо, що цей аспект потребує окремої уваги.

Мета статті - виокремити і проаналізувати прояви критики різних ідеологій в українському історико-педагогічному наративі радянської доби (1920-1980).

Виклад основного матеріалу. Серед основних об'єктів критики (в річищі “війни ідеологій”) радянських ідеологів були ліберальна, соціал-демократична, націоналістична, фашистська та націонал-соціалістична, консервативна ідеологічні системи. Аналіз історико-педагогічних творів вітчизняних учених радянської України засвідчує, що ці “лінії наступу” відобразилися і в їхніх дослідженнях.

Критика лібералізму. У багатьох працях з історії педагогіки, опублікованих вітчизняними дослідниками у 1920-1980-ті рр. був помітним зневажливий рефрен щодо ліберальної ідеології. Зокрема, Я. Ряппо у 1927 р. таврував “ліберальнодемократичну буржуазію” початку XX ст. за начебто відсутність шляхів розв'язання національного питання в їхній ідеології, вів мову про “брехливі гасла ліберальної демократії” [18, 8, 13]. С. Збандуто у статті про педагогічні погляди М. Чернишевського (1939) зневажливо відгукувався про лібералів [7, 36, 45]. В. Дем'яненко (1941), аналізуючи педагогічну діяльність М. Пирогова в Одесі, навів слова В. Леніна про лібералів як ідеологів буржуазії, які хочуть звільнити Росію зверху, не руйнуючи монархії, про страх лібералів перед революцією і рухом мас [4, 52]. Назвавши М. Пирогова ідеологом буржуазії, автор осудливо поставився до критики ним соціалізму та схвальних оцінок права власності [4, 53-54]

Антиліберальні інвективи продовжувалися і після Другої світової війни. Зокрема, С. Чавдаров у статті про погляди К. Ушинського (1946) писав про “справжні мотиви ліберальних освітніх заходів експлуататорських класів” [29, 18], звісно, маючи на увазі начебто антидемократичність цих мотивів. О. Дзеверін, аналізуючи педагогічні погляди А. Чехова (1954), вважав, що російський письменник "високо піднісся над обмеженим рівнем лібералізму, виступивши з протестом проти теорії “малих справ”, як теорії, що означала ухиляння від докорінного розв'язання багатьох питань соціального життя" $[6,18]$. Л. Пятко (1974), пишучи про Всеросійський з'їзд $з$ народної освіти 1913-1914 рр., визнав, що ліберальна частина буржуазії і поміщиків виступала за “деяке поширення освіти”. Проте одразу вказав: таке “піклування" (sic!) було викликане не стільки інтересами буржуазії, скільки невпинним зростанням революційного руху $[16,42]$. Тож дослідник, по-суті, навіть цю частину лібералів уважав недостатньо прогресивною силою, котра просто змушена була враховувати наростання революційної боротьби нижчих класів.

Об'єктом критики став й український ліберальний рух другої половини ХІХ ст., який набув виразного національного забарвлення. В. Борисенко (1980) зобразив українських лібералів лише позірними борцями проти національного гноблення, людьми, котрі “прикривались” загальнонаціональними інтересами і намагалися “відвернути увагу трудящих мас від пекучих соціально-економічних і політичних проблем", зміцнити позиції панівних верств України $[1,102]$. У непривабливих тонах автор змалював “громади" - організації “ліберально-буржуазної інтелігенції”, які начебто й боролися за освіту народу, але у своїх інтересах [1, 102-104]. Зрештою, лібералів учений затаврував ленінським поняттям “лицемірні торгаші” $[1,153]$.

Критика соиіал-демократичних ідей. Історики педагогіки, які жили й працювали в умовах становлення тоталітарного суспільства, перейняли ідеологічне протистояння радянських партійно-політичних ідеологів із західними соціалдемократичними рухами. Для прикладу, М. Левіна у 1933 р. виступила з викривальною статтею історико-педагогічного і полемічного характеру щодо фальсифікацій марксизму у галузі освіти. Дослідниця цілковито розкритикувала соціал-демократів міжвоєнного періоду за начебто “остаточний відхід від Маркса", схильність до фашизму, формування шкіл, зміст освіти в яких “діяметрально протилежний” марксистським настановам про навчання і виховання [10, 146, 148-149]. Прагнучи показати іхню слабкість, вона вказала на партикулярність західної соціал-демократії (права течія у німецькій соціал-демократії, амстердамський інтернаціонал, ліві представники “австрійської школи” та ін). Намагаючись довести істинність радянського політико-ідеологічного вектору, М. Левіна використала слова Й. Сталіна: “ленінізм марксизмом нашої доби” [10, 146]. 


\section{ІДЕОЛОГІЧНА КРИТИКА В УКРАЇНСЬКОМУ РАДЯНСЬКОМУ}

ІСТОРИКО-ПЕДАГОГІЧНОМУ НАРАТИВІ (1920-1980)

У 1938 p. А. Слуцький у журналі “Комуністична освіта" вдався до критики соціалреформістських партій, які входили до II Інтернаціоналу, назвавши іх угодовськими. Особливо критикував християнсько-соціалістичні партії. На його думку, у самій назві цих політичних організацій міститься неприхована суперечність, бо “....сціалізм і християнство можна з’єднати тільки ціною цілковитого збесмислювання ідей соціалізму” [20, 54]. Я. Ряппо у 1927 р. ідеологію соціал-революціонерів та меншовиків визнав найшкідливішою та найворожішою до “могутнього руху”, що спричинив “Жовтневу революцію” $[18,13]$. Т. Чугуєв, описуючи погляди В. Леніна на вчительство колишньої Росії (1941), зазначив: “...есерівська партія була найзлішим ворогом Жовтневої революції” [30, 10$]$. Європейські соціал-демократичні партії початку XX ст. С. Литвинов у праці про педагогічні погляди Н. Крупської (1949) назвав опортуністичними, приписавши їм “витончену оману трудящих” $[11,15]$.

Критика ідеологічних “ухилів”. Історикопедагогічний наратив українських учених у 1930ті pp. заполонили випади проти “внутрішніх ворогів” соціалістичної ідеології, погляди яких не збігалися з візіями радянських лідерів. Одним із перших об'єктів постійних ідеологічнопропагандистських інвектив став “троцькізм”, котрий $з$ подачі Й. Сталіна визнано відхиленням від ленінського вчення. У статті про завдання “робітників ідеологічного фронту” (1932), під якими малися на увазі насамперед науковці, М. Скрипник переказав слова Й. Сталіна, якими той ганьбив спроби троцькістів “фальшувати історію нашої партії і під ленінсько-більшовицькою фразеологією протаскувати троцькістську контрабанду в нашу партію” [19, 19]. Автор наголосив, що слід на кожній ділянці “практичної і теоретичної роботи” (у тому числі наукової), “зустрічаючись з фальшуванням ленінізму, з контрабандою ворожнечої ідеології в нашому таборі, виявляти це і переборювати”. При цьому повторював слова більшовицького лідера про неприпустимість дискусії з питань, які $\epsilon$ “аксіомами більшовизму” [19, 20]. Відтак будьяке відхилення від офіційної ідеології вважалося злочинним, а політичний плюралізм цілковито відкидався.

Про складні перипетії внутрішньопартійної та ідеологічної боротьби в СРСР свідчить праця А. Зільберштейна, присвячена педагогічним поглядам В. Леніна (1934). Професор вів мову про “величезні історичні перемоги”, досягнуті під проводом компартії, яка в боротьбі за “генеральну ленінську лінію” розтрощила “контрреволюційний троцькизм”, боролася на два фронти проти правого опортунізму, “лівацьких закрутів” та примиренства [8, 9]. Пишучи про культурну революцію, автор узявся критикувати погляди меншовиків і Л. Троцького. Першим дорікав за твердження про неможливість культурного визрівання пролетаріату в умовах капіталізму (бо цим “зрадницьким твердженням хотіли лише відсунути пролетарську революцію”). Другого ж таврував за думку, що доки не відбудеться світова пролетарська революція, пролетаріат не здатен створити будь-яку нову культуру, зможе лише користуватися здобутками буржуазної культури, буде вчитися у буржуазії $[8,10]$. Накинувся і на “право-опортуністичні установки” М. Бухаріна, котрий начебто неправильно розумів диктатуру пролетаріату як мирне співробітництво класів, говорив про припинення класової боротьби та “вростання куркуля в соціалізм” $[8,11]$

Поряд 3 цим у 1930-і рр. до історикопедагогічних праць вітчизняних дослідників проникла ідеологічна критика усіляких “ухилів”. Так, А. Зільберштейн у 1934 р. взявся викривати “націоналістичний ухил” М. Скрипника, який, за словами професора, сприяв “контрреволюційній діяльності українських націоналістів”. Українському радянському діячеві, який роком раніше наклав на себе руки, закидалося грубе перекручування поглядів В. Леніна та Й. Сталіна щодо національної політики, “замазування” ролі більшовицьких вождів як творців марксистської візії національного питання у партії та Комінтерні, переоцінку національного чинника, увагу до розвитку не класової, а національної свідомості, надання “націоналістичних установок” у питаннях історії, освіти, мистецтва. Повторюючи ідеологічні штампи С. Косіора та В. Постишева, харківський учений дорікав М. Скрипнику у формуванні систематичної лінії на ослаблення господарських, державних, культурних зв'язків України з іншими радянськими республіками, на “максимальний відрив української мови від руської”, тенденції до проведення насильної українізації [8, 14-15].

Услід за А. Зільберштейном ідеологічну критику поглядів М. Скрипника впровадив до свого наративу О. Дзеверін, опублікувавши статтю про погляди В. Леніна на національне виховання молоді (1934). Учений запевняв у наявності активізації “буржуазно-націоналістиних елементів на Україні” у 1930-1932 рр. у зв’язку з начебто пропагуванням М. Скрипником та його прибічниками “цілої націоналістичної системи поглядів і впровадженням ними націоналістичних збочень у практиці освітньо-виховної роботи" [5, 9]. Подібно й С. Чавдаров у 1935 р. обвинуватив 


\section{ІДЕОЛОГІЧНА КРИТИКА В УКРАЇНСЬКОМУ РАДЯНСЬКОМУ ІСТОРИКО-ПЕДАГОГІЧНОМУ НАРАТИВІ (1920-1980)}

екс-керівників Наркомосу України О. Шумського та М. Скрипника у шкідницькій роботі $[27,39]$.

Критика фашизму та націонал-соціалізму. Антифашистська пропаганда, яка зросла в СРСР після приходу до влади в Німеччині нацистів на чолі 3 А. Гітлером, проникала й до історикопедагогічних праць. У статті О. Попіва, присвяченій поглядам К. Маркса та Ф. Енгельса на феномен дитинства (1933), здійснено випад проти фашистських організацій різних країн, які “намагаються 3 дітей трудящих вербувати собі вірних яничарів фашизму” $[15,21]$. С. Чавдаров (1935), аналізуючи здобутки радянської педагогіки за попередні роки, ганьбив німецький фашизм за впровадження навчальної дисципліни “расознавство” та увів до свого наративу пропагандистський вислів: “Фашизм - могильщик культури - інтенсивно нищить основи наук у своїх школах, бо ці школи мусять випускати для Гітлера солдатів, для монополістичної буржуазії - сліпу, начинену маніакальними ідеями масу, гідну для убоя заради їі, буржуазії, інтересів" [27, 44]. Загалом критика фашизму і нацизму була характерною ознакою ідеологічного субстрату українського історико-педагогічного наративу радянської доби.

Критика украӥнського націоналізму. Як відомо, об'єктом критики радянських ідеологів був “український буржуазний націоналізм”, який ототожнювали з фашизмом. Історики педагогіки у своїх працях також взялися “громити” його, часто використовуючи при цьому політико-партійні штампи. Так, А. Зільберштейн (1934) на основі доповідей партійно-політичних лідерів УСРР С. Косіора та В. Постишева на листопадовому (1933) пленумі ЦК КП(б)У, вів мову про “...зв’язок недобитків української буржуазії зі старими вождями української контрреволюції, 3 німецькими фашистами та польськими поміщиками" [8, 14]. Особливо обурила автора “рознуздана інтервенціоністська кампанія проти робітників і селян України”, яку проводили за кордоном у той час (де якраз писали про голод в Україні). Зрештою, дослідник об’єднав в одну групу “троцькістів”, “гітлерівських наймитів 3 української військової організації”, “рештки” українських есерів і соціал-демократів $[8,14]$.

У 1934 р. побачила світ викривальнопропагандистська стаття I. Хаїта (згодом перевидана як брошура) “За більшовицьку розчистку на фронті педагогічної теорії”. У ній автор накинувся на сформовану у 1920-х рр. “харківську педагогічну школу” (І. Сколянський, О. Залужний, О. Попов), назвавши іiї школою “українського фашизму” - та "рідною сестрою педагогічних шкіл німецького, італійського, українського закордонного та іншого фашизмів" $[23,15]$. Один із підрозділів праці I. Хаїта мав метафоричну назву “Про чорта жовтого та чорта синього" [23, 21-30], а стиль нагадував пасквіль. Відзначимо, що подібне ідеологічне означення (“націонал-фашистська педагогічна школа”) для харківських педологів у 1935 р. вжив і С. Рубінштейн [17].

До “українських націоналістів” історики педагогіки, услід за політико-ідеологічними діячами зарахували значну кількість діячів української науки. Зокрема, А. Хвиля у статті про історію Київського університету (1936) назвав професора цього закладу В. Антоновича “українським націоналістом" та “божком українського націоналістичного табору” [25, 11]. I. Хаїт у тому ж році взявся викривати українофілів середини ХІХ ст. як родоначальників українського націоналізму. Вів мову про “жалюгідну роль професорів-українофілів” у Харківському університеті. Вірнопідданські настрої і дволичність побачив у діяльності П. ГулакаАртемовського та М. Костомарова [24, 31]. Таким чином, автор наголошував на лояльності українофілів до царського режиму, а звідти намагався вивести спорідненість українського націоналізму з російським самодержавством.

Критика українського націоналізму як ідеології набрала обертів після Другої світової війни, коли в західних регіонах України розгорнувся визвольний рух під проводом ОУН і УПА. До ідеологів націоналізму радянські ідеологи, а услід за ними і науковці, зарахували у той час уже покійного главу Української греко-католицької церкви А. Шептицького. Тут їм часто ставали в нагоді дискусія I. Франка 3 митрополитом на початку ХХ ст. Так, С. Чавдаров у 1946 р. намагався подати начебто різку критику українським письменником поглядів провідника унійної церкви: “Шептицький звинувачує соціалістів у тому, що вони відкидають правду і перешкоджають народному добру. Франко на це відповідав: “Соціалізм не перечить ніякій правді”” $[28,5]$. Відтак професор наголосив, що І. Франкові був чужим будь-який націоналізм, “який так насаджувався в Галичині” [28, 8].

Оскільки на західноукраїнських землях у 1940 - на початку 1950-х рр. під гаслами націоналізму діяло збройне підпілля, то в історико-педагогічні праці радянських авторів закономірно вмонтовувалися відповідні політико-ідеологічні тези. Зокрема, Г. Пінчук у статті про розвиток радянської школи від 1939 до 1949 рр., запевняв: трудящі західних областей “переконалися в тому, 


\section{ІДЕОЛОГІЧНА КРИТИКА В УКРАЇНСЬКОМУ РАДЯНСЬКОМУ ІСТОРИКО-ПЕДАГОГІЧНОМУ НАРАТИВІ (1920-1980)}

що українські буржуазні націоналісти, які стільки галасували й галасують про “самостійну” Україну, - це жорстокі, підступні вороги українського народу, шпигуни й наймити імперіалістичних держав, які домагаються того, щоб занапастити український народ, продати його в кабалу іноземним імперіалістам-хижакам" [14, 9]. Ю. Ступак у статті про педагогічні думки М. Коцюбинського (1953) приписав українським націоналістам служіння царському уряду i відданість монархії взамін за дозвіл на деякі заходи культурного характеру [22, 24-25]. Ще химернішим виявилося твердження М. Грищенка (1960), згідно з яким “українські буржуазні націоналісти” були “надійними помічниками польських окупантів на західноукраїнських землях" у міжвоєнні роки $[3,34]$. О. Кондратюк (1979) зобразив “українських буржуазних націоналістів” спільниками гітлерівців та “бандитами” і взявся наводити “факти” їхнього терору проти вчителів і учнів у західних областях України у перші повоєнні роки $[9,13 ; 14]$.

До ідеологічної боротьби проти українського націоналізму долучали й авторитет національних геніїв. Так, О. Мазуркевич (1954) підкреслив, що Т. Шевченко виступав проти “українських буржуазних націоналістів” [13, 26], а I. Ходорківський (1954) запевняв: український поет свій “Буквар" протиставляв “буржуазнонаціоналістичній, антинародній за своїм спрямування “Граматці” Куліша” [26, 61]. Згодом О. Мазуркевич (1963) зобразив начебто негативне ставлення Х. О. Алчевської до “українських буржуазних націоналістів” [12, 6768]. В. Смаль (1971) стверджував, що Леся Українка осуджувала “буржуазно-націоналістичних діячів”, які “спекулювали на темряві свого народу” i “базікали” про науку на національному грунті і народну освіту [21, 37 - 38]. Таких прикладів можна наводити багато.

Критика консерватизму в працях істориків педагогіки часто зосереджувалася навколо негативних оцінок релігійних учень, однак це питання є доволі об'ємним й потребує розгляду в окремій публікації.

Висновки. Отже, під тиском притаманної для радянського тоталітаризму моноідеологічності, а саме цілковитого домінування однієї ідеології (соціалістичної у формі “марксизму-ленінізму”), у вітчизняному історико-педагогічному наративі звичними стали оцінки фактів і процесів педагогічної минувшини крізь призму саме ідеологічних постулатів. Це проявилося, зокрема, у критиці ліберальних, консервативних, націоналістичних, націонал-соціалістичних, соціал- демократичних ідей та їхніх репрезентантів в освіті та педагогічній науці.

Перспективним напрямом подальших досліджень вважаємо виявлення і аналіз інших аспектів впливу соціалістичної ідеології та пропаганди.

\section{ЛІТЕРАТУРА}

1. Борисенко В. Й. Боротьба демократичних сил за народну освіту на Україні в 60 - 90-роках XIX ст. Київ: “Наукова думка”, 1980. 155 с.

2. Галів М. Український історико-педагогічний наратив (середина XIX - кінець XX ст.): епістемологічні засади. Дрогобич, 2018. 614 с.

3. Грищенко М. М. Народна освіта в західних областях Української РСР. Київ: Радянська школа, 1960. $158 \mathrm{c}$.

4. Демьяненко В. Общественно-педагогическая деятельность Н.И. Пирогова в Одессе. Труды Одесского государственного университета. Сборник кафедры педагогики. Одесса, 1941. Т. II. C. 51-77.

5. Дзеверін О. Ленін про національне виховання молодих поколінь. Комуністична освіта. 1934. № 4. С. $8-18$.

6. Дзеверін О. Г. Питання освіти і школи в творчості А. П. Чехова. Радянська школа. 1954. № 7. С. 10-19.

7. Збандуто С. Великий революціонер-педагог (до 50-річчя з дня смерті М.Г. Чернишевського). Комуністична освіта. 1939. № 10. С. 35-46.

8. Зільберштейн А. І. Ленін про культурну революцію та завдання освіти. Комуністична освіта. 1934. № 1. С. 8-29.

9. Кондратюк О. П. Кроки боротьби і перемоги (До 40-річчя возз'єднання західноукраїнських земель з радянською Україною). Радянська школа. 1979. № 10. С. 11-14.

10. Левіна М. Соціял-фашистські фальсифікації марксизму в галузі освіти. Комуністична освіта. 1933. № 5. С. 146-150.

11. Литвинов С. А. Н. К. Крупська-видатний радянський педагог. Радянська школа. 1949. №1. C. 14-19.

12. Мазуркевич О. Р. Визначні українські педагоги - народні просвітителі. Х. Д. Алчевська та іiі сподвижники. Київ: Товариство “Знання” УРСР, 1963. 79 с.

13. Мазуркевич О. Р. Творчість Т. Г. Шевченка в педагогічній спадщині передових діячів російської школи . Радянська школа. 1954. № 1. C. 26-37.

14. Пінчук Г. П. Славне десятиріччя. Народна освіта Української РСР до десятиріччя возз'єднання українського народу в єдиній 


\section{ІДЕОЛОГІЧНА КРИТИКА В УКРӒ̈НСЬКОМУ РАДЯНСЬКОМУ ІСТОРИКО-ПЕДАГОГІЧНОМУ НАРАТИВІ (1920-1980)}

Українській Радянській державі. Радянська школа. 1949. № 5. С. 1-16.

15. Попів О. Проблема дитинства в творах Маркса й Енгельса. Комуністична освіта. 1933. № 4. С. 16-40.

16. Пятко Л. П. І-й Всеросійський з'їзд 3 народної освіти. Радянська школа. 1974. № 7. C. $42-47$.

17. Рубінштейн С. Вікові особливості дітей у висвітленні "Харківської націонал-фашистської педагогічної школи”. Комуністична освіта. 1935. № 1. С. 70-74.

18. Ряппо Я. Що дала Жовтнева революція в галузі освіти на Україні. Харків: Книгоспілка, 1927. $104 \mathrm{c}$.

19. Скрипник М. Лист тов. Сталіна до редакції журнала "Пролетарская революция” та завдання робітників ідеологічного фронту. Комуністична oсвima. 1932. № 1-2. С. 19-29.

20. Слуцький А. Історичний декрет. Комуністична освіта. 1938. № 2. С. 53-57.

21. Смаль В. 3. Леся Українка і народна освіта. Радянська школа. 1971. № 2. С. 35-41.

22. Ступак Ю. П. М. М. Коцюбинський про освіту і виховання. Радянська школа. 1953. № 6. C. $20-31$.

23. Хаїт I. За більшовицьку розчистку на фронті педагогічної теорії. Комуністична освіта. 1934. № 2. C. 10-50.

24. Хаїт I. Про історичну неправду і історичну правду. Комуністична освіта. 1936. № 3. Додаток. С. 28-32.

25. Хвиля А. Сто років. Комуністична освіта. 1936. № 3. Додаток. С. 4-27.

26. Ходорківський І. Д. [рецензія] Проф. С. Х. Чавдаров. Педагогічні ідеї Тараса Григоровича Шевченка, 1953, 207 стор. Радянська школа. 1954. № 1. С. 57-62.

27. Чавдаров С. Проти залишків безглуздої теорії “відмирання школи” в навчальних планах початкової та середньої школи. Комуністична oсвima. 1935. № 10. С. 38-45.

28. Чавдаров С. Х. Іван Франко про мораль і моральне виховання. Радянська школа. 1946. №4. C. 4-11.

29. Чавдаров С. Х. К. Д. Ушинський - великий педагог нашої Батьківщини. Радянська школа. 1946. № 1-2. С. 16-24.

30. Чугуєв Т. В. І. Ленін про вчительство. Комуністична освіта. 1941. № 4. С. 6-15.

\section{REFERENCES}

1. Borysenko, V.Y.(1980). Borotba demokratychnykh syl za narodnu osvitu na Ukraini v 60 - 90-rokakh XIX st. [The struggle of democratic forces for public education in Ukraine in the $60-90$-ies of the XIX century]. Kyiv, 155 p. [in Ukrainian]

2. Haliv, M. (2018). Ukrainskyi istorykopedahohichnyi naratyv (seredyna XIX - kinets XX st.): epistemolohichni zasady [Ukrainian historical and pedagogical narrative (mid-XIXth - late XXth century]. Drohobych, 614 p. [in Ukrainian].

3. Hryshchenko, M. M. (1960). Narodna osvita v zakhidnykh oblastiakh Ukrainskoi RSR [Public education in the western regions of the Ukrainian SSR]. Kyiv, 158 p. [in Ukrainian].

4. Demianenko, V. (1941). Obshchestvennopedagogicheskaia deiatelnost N.I. Pirogova v Odesse [Social and pedagogical activities of N.I. Pirogov in Odessa]. Proceedings of Odessa State University. Collection of the Department of Pedagogy, II, pp. 51-77. [in Russian].

5. Dzeverin, O. (1934). Lenin pro natsionalne vykhovannia molodykh pokolin [Lenin on the national education of young generations]. Communist education, 4, pp. 8-18. [in Ukrainian].

6. Dzeverin, O. H. (1954). Pytannia osvity i shkoly $v$ tvorchosti A. P. Chekhova [Issues of education and school in the work of A.P. Chekhov]. Soviet school, 7, pp. 10-19. [in Ukrainian].

7. Zbanduto, S. (1939). Velykyi revoliutsionerpedahoh (do 50-richchia z dnia smerti M.H. Chernyshevskoho) [The great revolutionaryteacher (to the 50th anniversary of the death of M.G. Chernyshevsky)]. Communist education, 10, pp. 35-46. [in Ukrainian].

8. Zilbershtein, A. I. (1934). Lenin pro kulturnu revoliutsiiu ta zavdannia osvity [Lenin on the cultural revolution and the task of education]. Communist education, 1, pp. 8-29. [in Ukrainian]

9. Kondratiuk, O. P. (1979). Kroky borotby i peremohy (Do 40-richchia vozziednannia zakhidnoukrainskykh zemel z radianskoiu Ukrainoiu) [Steps of struggle and victory (To the 40th anniversary of the reunification of Western Ukrainian lands with Soviet Ukraine)]. Soviet school, 10, pp. 11-14. [in Ukrainian].

10. Levina, M. (1933). Sotsiial-fashystski falsyfikatsii marksyzmu v haluzi osvity [Social-fascist falsifications of Marxism in education]. Communist education, 5, pp. 146-150. [in Ukrainian].

11. Lytvynov, S. A. (1949). N. K. Krupska vydatnyi radianskyi pedahoh [N.K. Krupskaya - an outstanding Soviet teacher]. Soviet school, 1, pp. 14 19. [in Ukrainian].

12. Mazurkevych, O. R. (1963). Vyznachni ukrainski pedahohy - narodni prosvityteli. Kh. D. Alchevska ta yii spodvyzhnyky [Prominent Ukrainian teachers - folk educators. Kh. D. Alchevska and her associates]. Kyiv, 79 p. [in Ukrainian]. 


\section{ІДЕОЛОГІЧНА КРИТИКА В УКРАЇНСЬКОМУ РАДЯНСЬКОМУ ІСТОРИКО-ПЕДАГОГІЧНОМУ НАРАТИВІ (1920-1980)}

13. Mazurkevych, O. R. (1954). Tvorchist T. H. Shevchenka v pedahohichnii spadshchyni peredovykh diiachiv rosiiskoi shkoly [Creativity of Taras Shevchenko in the pedagogical heritage of leading figures of the n school]. Soviet school, 1, pp. 26-37. [in Ukrainian].

14. Pinchuk, H. P. (1949). Slavne desiatyrichchia. Narodna osvita Ukrainskoi RSR do desiatyrichchia vozziednannia ukrainskoho narodu v yedynii Ukrainskii Radianskii derzhavi [The glorious decade. Public education of the Ukrainian SSR to the tenth anniversary of the reunification of the Ukrainian people in a single Ukrainian Soviet state]. Soviet school, 5, pp. 1-16. [in Ukrainian].

15. Popiv, O. (1933). Problema dytynstva $v$ tvorakh Marksa y Enhelsa [The problem of childhood in the works of Marx and Engels]. Communist education, 4, pp. 16-40. [in Ukrainian].

16. Piatko L. P. (1974). I-y Vserosiiskyi zizd z narodnoi osvity [The First All-Russian Congress of Public Education]. Soviet school, 7, pp. 42-47. [in Ukrainian].

17. Rubinshtein, S. (1935). Vikovi osoblyvosti ditei u vysvitlenni "Kharkivskoi natsional-fashystskoi pedahohichnoi shkoly" "Age features of children in the coverage of "Kharkiv National-Fascist Pedagogical School"]. Communist education, 1, pp. 70-74. [in Ukrainian].

18. Riappo, Ya. (1927). Shcho dala Zhovtneva revoliutsiia v haluzi osvity na Ukraini. Kharkiv, $104 \mathrm{p}$. [in Ukrainian].

19. Skrypnyk, M. (1932). Lyst tov. Stalina do redaktsii zhurnala "Proletarskaia revoliutsyia" ta zavdannia robitnykiv ideolohichnoho frontu [Letter comrade Stalin to the editors of the magazine "Proletarian Revolution" and the tasks of the workers of the ideological front]. Communist education, 12, pp. 19-29. [in Ukrainian].

20. Slutskyi, A. (1938). Istorychnyi dekret [Historical decree]. Communist education, 2, pp. $53-$ 57. [in Ukrainian].
21. Smal, V. Z. (1971). Lesia Ukrainka i narodna osvita [Lesya Ukrainka and public education]. Soviet school, 2, pp. 35-41. [in Ukrainian].

22. Stupak, Yu. P. (1953). M. Kotsiubynskyi pro osvitu i vykhovannia [M. Kotsyubynsky on education and upbringing]. Soviet school, 6, pp. 20-31. [in Ukrainian].

23. Khait, I. (1934). Za bilshovytsku rozchystku na fronti pedahohichnoi teorii [For the Bolshevik clearing on the front of pedagogical theory]. Communist education, 2, pp. 10-50. [in Ukrainian].

24. Khait, I. (1936). Pro istorychnu nepravdu i istorychnu pravdu [On historical untruth and historical truth]. Communist education, 3 (Supl.), pp. 28-32. [in Ukrainian].

25. Khvylia, A. (1936). Sto rokiv [One hundred years]. Communist education, 3 (Supl.), pp. 4-27. [in Ukrainian].

26. Khodorkivskyi, I. D. (1954). [retsenziia] Prof. S. Kh. Chavdarov. Pedahohichni idei Tarasa Hryhorovycha Shevchenka, 1953, 207 stor. [review on: Prof. S. Kh. Chavdarov. Pedagogical ideas of Taras Shevchenko, 1953, 207 pages]. Soviet school, 1, pp. 57-62. [in Ukrainian].

27. Chavdarov, S. (1935). Proty zalyshkiv bezghluzdoi teorii “vidmyrannia shkoly" v navchalnykh planakh pochatkovoi ta serednoi shkoly [Against the remnants of the absurd theory of "school extinction" in the curricula of primary and secondary schools]. Communist education, 10, pp. 38-45. [in Ukrainian].

28. Chavdarov, S. Kh. (1946). Ivan Franko pro moral i moralne vykhovannia [Ivan Franko on morality and moral education]. Soviet school , 4, pp. 4-11. [in Ukrainian].

29. Chavdarov, S. Kh. (1946). K. D. Ushynskyi - velykyipedahoh nashoi Batkivshchyny [K. D. Ushinsky - a great teacher of our country]. Soviet school, 1 2, pp. 16-24. [in Ukrainian].

30. Chuhuiev, T. (1941). V. I. Lenin pro vchytelstvo [Lenin on teaching]. Communist education, 4, pp. 6-15. [in Ukrainian].

Стаття надійшла до редакції 03.08.2020

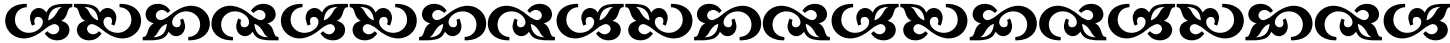

"Жастя полягає в тому, щоб, відқривши у собі справжню до чогось здібність, побудувати на ній своє життя".

Тригорій Сковорода украйнський ббілософ, педагог

"Метаббори й історії набагато сильніші (на жаль) за ідеї. Iдеї з'являються й зникають, історії-залишаються".

Насім ТТалеб

лівансько-американський літератор, науковеиь

\section{}

